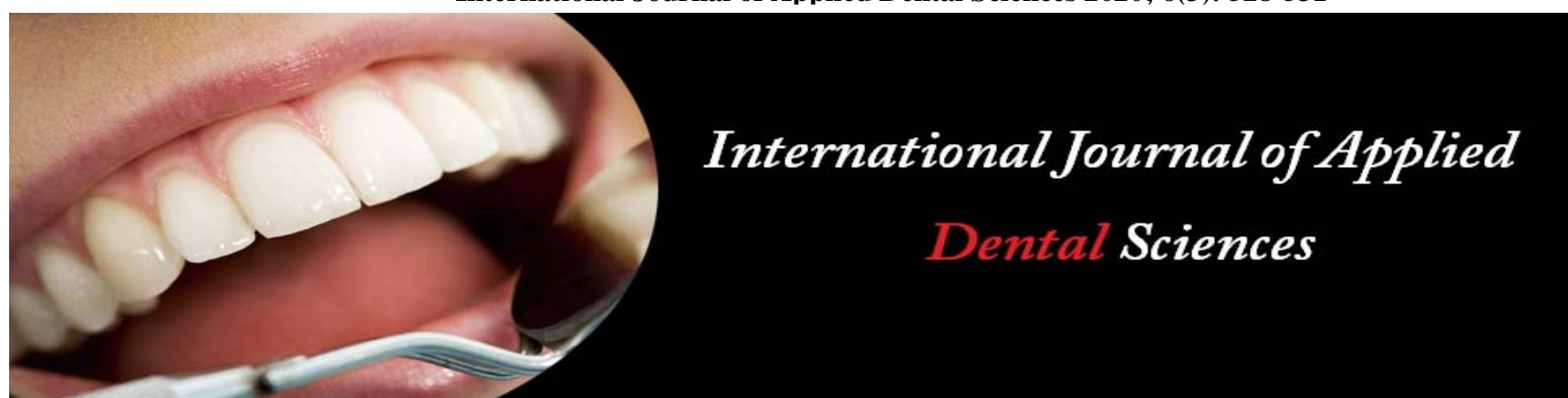

ISSN Print: 2394-7489 ISSN Online: 2394-7497 IJADS 2020; 6(3): 528-531 (C) 2020 IJADS www.oraljournal.com Received: 10-05-2020 Accepted: 19-06-2020

Dr. Mohsin Khan Senior Lecturer, Department of Public Health Dentistry, Vyas Dental College and Hospital, Rajasthan, India

Dr. Mridul Sharma B.D.S, Visiting consultant at City Dental, Jodhpur,

Rajasthan, India
Corresponding Author: Dr. Mohsin Khan Senior Lecturer,

Department of Public Health Dentistry, Vyas Dental College and Hospital, Rajasthan, India

\section{Comparison of efficacy of different storage media for an avulsed tooth}

\author{
Dr. Mohsin Khan and Dr. Mridul Sharma
}

DOI: $\underline{\text { https://doi.org/10.22271/oral.2020.v6.i3h.1006 }}$

\section{Abstract}

Exarticulation or dental avulsion is considered as the most serious type of traumatic tooth injuries. The most common management of avulsion is reimplantation which is widely accepted as an effective treatment, but it depends on various factors such as extra alveolar storage period, vitality status of pulp and periodontal tissue. The important clinical factor for better prognosis is the appropriate use of wet storage media. The present review discusses the wide array of different types of wet storage media and the comparison of their clinical factors such as osmolarity, $\mathrm{pH}$, storage time on their efficacy.

Keywords: storage medium, osmolarity, efficacy, ph, periodontal ligament cells

\section{Introduction}

Dental Avulsion is a complete displacement of the tooth from its alveolus. It is also called exarticulation and mostly involves maxillary teeth. It is the most severe type of traumatic tooth injury because it causes damage to several structures. Ideally, the ex articulated tooth should be reimplanted immediately after the trauma. Reimplantation success rates depend on various factors that may contribute to accelerate or minimize the occurrence of root resorption among which is the type and characteristics of the medium used for temporary storage during the time elapsed between avulsion and reimplantation. Teeth are usually subjected to a period of desiccation between their avulsion and reimplantation. Therefore it is desirable to reimplant the avulsed tooth as quickly as possible to ensure the viability of PDL cells attached to the root surface. The avulsed tooth must be prevented from drying by the use of storage media of correct osmolarity and $\mathrm{pH}$. In the case where immediate reimplantation is not possible, the use of a storage medium helps to enhance and preserve the vitality of PDL fibroblast of an avulsed tooth. Tooth structure should be preserved inadequate wet medium as long as possible, the vitality of periodontal ligament cells that remain on the root surface is key to the success of reimplantation. The ideal storage medium should be capable of preserving the feasibility of cellular periodontal ligament so that the cell could go through mitosis and form clones of damaged fibroblast of the periodontal ligament and its generating cells. Immediate tooth reimplantation leads to better PDL repair and reduces the root resorption. Shortening of possible time elapsed between trauma and tooth reimplantation and maintaining the avulsed tooth in suitable transport medium attenuate the deleterious effects and increase the prognosis considerably. There are different storage media that are available but their efficacy varies. An ideal storage media must be capable of maintaining PDL and pulp cell viability should have the clonogenic capacity and antioxidant property, no or less microbial contamination, compatible physiologic $\mathrm{pH}$ and osmolarity, high availability and low cost.

\section{Ideal requirements of a storage media}

- Should have antimicrobial characteristics.

- Should be able to maintain the viability of periodontal fibres for an acceptable period of time.

- It should have the same osmolarity as that of body fluids.

- It should not produce any antigen-antibody reaction. 
- It should have a good shelf life

- It should wash off extraneous materials and toxic waste products.

- It should aid in the reconstitution of depleted cellular metabolites.

\section{Various types of storage/ transport media}

There are different types of wet storage media for avulsed teeth, which may vary from the cell and tissue culture solution like Hank balanced salt solution (HBSS); Medical product developed specifically for organ storage purpose such as viaspan; Saline; Natural products like water, saliva, milk, propolis, egg white, coconut water; Rehydrating solutions like Gatorade and ricetral; and even contact lens solution.

The osmolarity, $\mathrm{pH}$, efficacy, and accessibility for different wet storage media for an avulsed tooth is described and summarized in this review.

Table 1: Categorization of storage media according to their osmolarity

\begin{tabular}{|c|c|c|}
\hline S. No & Storage medium & Osmolarity \\
\hline 1. & Saline & $280 \mathrm{mOsm} / \mathrm{kg}$ \\
\hline 2. & Tap water & $290 \mathrm{mosm} / \mathrm{kg}$ \\
\hline 3. & Saliva & $60 \mathrm{mosm} / \mathrm{kg}$ \\
\hline 4. & Milk & $300 \mathrm{osm} / \mathrm{kg}$ \\
\hline 5. & HBSS & $320 \mathrm{mosm} / \mathrm{kg}$ \\
\hline 6. & Viaspan & $320 \mathrm{osm} / \mathrm{kg}$ \\
\hline 7. & Gatorade & $280-360 \mathrm{osm} / 1$ \\
\hline 8. & Propolis & $350 \mathrm{osm} / 1$ \\
\hline 9. & Emdogain & $407 \mathrm{mosm} / \mathrm{kg}$ \\
\hline 10. & Egg white & $300 \mathrm{mosm} / \mathrm{kg}$ \\
\hline 11. & Eagles Medium & $310-360 \mathrm{mosm} / \mathrm{kg}$ \\
\hline 12. & L-DOPA & $238 \mathrm{mosm} / \mathrm{kg}$ \\
\hline 13. & Cocunut water & $288 \mathrm{mosm} / 1$ \\
\hline 14. & Contact lens solution & $310 \mathrm{mosm} / \mathrm{kg}$ \\
\hline
\end{tabular}

Table 2: Categorization of storage media according to their $\mathrm{pH}$

\begin{tabular}{|c|c|c|}
\hline S. No & Storage Media & pH \\
\hline 1. & Saline & 5.5 \\
\hline 2. & Tap water & 7 \\
\hline 3. & Saliva & 7.3 \\
\hline 4. & Milk & $6.7-6.9$ \\
\hline 5. & HBSS & $7.2-7.4$ \\
\hline 6. & Viaspan & 7.4 \\
\hline 7. & Gatorade & 3 \\
\hline 8. & Propolis & 5.1 \\
\hline 9. & Emdogain & 4.5 \\
\hline 10. & Egg white & 9.2 \\
\hline 11. & Eagles Medium & $6.8-7.2$ \\
\hline 12. & L-DOPA & $2.3-8.11$ \\
\hline 13. & Cocunut water & $5-5.4$ \\
\hline 14. & Contact lens solution & 7.8 \\
\hline
\end{tabular}

Table 3: Categorization of storage media according to their Storage time (shelf life)

\begin{tabular}{|c|c|c|}
\hline S. No & Storage Media & Storage Time \\
\hline 1. & Saline & $>2 \mathrm{hr}$ \\
\hline 2. & Tap water & $>1 \mathrm{hr}$ \\
\hline 3. & Saliva & $>1 \mathrm{~h} \mathrm{r}$ \\
\hline 4. & Milk & $6 \mathrm{hrs}$ \\
\hline 5. & HBSS & 2 years \\
\hline 6. & Viaspan & $144 \mathrm{hrs}$ \\
\hline 7. & Gatorade & $>1 \mathrm{hr}$ \\
\hline 8. & Propolis & $20 \mathrm{hrs}$ \\
\hline 9. & Emdogain & $>1 \mathrm{hr}$ \\
\hline 10. & Egg white & $6-10 \mathrm{hrs}$ \\
\hline 11. & Eagles Medium & $8 \mathrm{hr}-24 \mathrm{hr}$ \\
\hline 12. & L-DOPA & $>1 \mathrm{hr}$ \\
\hline 13. & Cocunut water & $>1 \mathrm{hr}$ \\
\hline 14. & Contact lens solution & $>1 \mathrm{hr}$ \\
\hline
\end{tabular}

\section{- Saline}

The saline solution provides an osmolarity of $280 \mathrm{mosm} / \mathrm{kg}$ and a $\mathrm{pH}$ of 5.5. It can be easily available but it lacks essential nutrients like ions and glucose which are fundamentals for the cells. It has a storage time of up to $2 \mathrm{hrs}$ and if it is used for a longer duration it starts deteriorating PDL cells.

Saline is not an adequate medium but because of its easy accessibility, it can be used for a short period of time.

\section{- Tap water}

Tap water is an unacceptable storage media for avulsed tooth because of its bacterial contamination, hypotonicity, and nonphysiologic $\mathrm{pH}$ and osmolarity. It causes PDL cell lysis and rapid cell death.

Thus water is not a suitable interim storage medium for retaining the viability of PDL cells.

\section{- Saliva}

Saliva can be used as storage media for a short period of time $(>1 \mathrm{hr})$. Its only advantage is easy accessibility. But it has unfavourable characteristics like high microbial contamination, non-physiologic $\mathrm{pH}$ and osmolarity and hypotonicity.

The osmolarity is much lower than physiologic saline, thus it boosts the harming effects of bacterial contamination.

\section{- Milk}

Milk is significantly better than other wet storage media because of its physiological properties, including $\mathrm{pH}$ and osmolarity compatible with those of cells from periodontal ligament. It is important that it is used in the first 20 min after avulsion. Milk contains essential epithelial growth factors which mainly stimulate the proliferation and regeneration of epithelial cell rest of malassez and activates the alveolar bone resorption. The pasteurization of milk is responsible for diminishing the various bacteria and bacteriostatic substances which could be harmful to the fibroblasts of the periodontal ligament. Blomlof (1983) and Trope and Freidman(1992) recommended milk as an excellent storing solution for $6 \mathrm{hrs}$, however, milk cannot revive the degenerated cells.

At the cellular level, milk is considered equal to hank balanced salt solution as a wet storage media but loses its effectiveness after 2 hrs. Thus milk is considered an adequate 
medium due to its beneficial effects, and characteristics, and ease of access at the moment of trauma.

\section{- Hank's balanced salt solution}

It is a standard saline solution that is non-toxic, biocompatible with periodontal ligament cells, $\mathrm{pH}$ balanced at 7.2 and has an osmolarity of $320 \mathrm{mosm} / \mathrm{kg}$. It mainly composed of $8 \mathrm{~g} / \mathrm{L}$ sodium chloride; $0.09 \mathrm{~g} / \mathrm{L}$ sodium phosphate; $0.14 \mathrm{~g} / \mathrm{L}$ potassium phosphate; $0.4 \mathrm{~g} / \mathrm{L}$ D- glucose; $0.4 \mathrm{~g} / \mathrm{L}$ potassium chloride; $0.35 \mathrm{~g} / \mathrm{L}$ sodium bicarbonate; $0.14 \mathrm{~g} / \mathrm{L}$ calcium chloride; $0.1 \mathrm{~g} / \mathrm{L}$ magnesium chloride; $0.1 \mathrm{~g} / \mathrm{L}$ magnesium sulphate; and also contains essential ingredients such as glucose, calcium and magnesium ions which can sustain and reconstitute depleted cellular components of periodontal ligaments cells. Ashkenazi et al. showed that HBSS was the most effective medium for preserving viability, mitogenicity, and clonogenic capacities of PDL cells for up to 24 hours at 4 ${ }^{\circ} \mathrm{C}$. It is commercially available as a SAVE-A-TOOTH which contains a soft membrane to minimize the cell trauma during transport.

\section{- ViaSpan}

ViaSpan is a medium used for the transportation of organs which are going to be transplanted and it has been an effective wet storage media for avulsed teeth. Its osmolarity is $320 \mathrm{mosm} / \mathrm{kg}$ and $\mathrm{pH}$ of 7.4 which is ideal for cell growth. It is developed to receive organs to be transplanted, have peculiar characteristics that allow maintaining cell viability, minimize damages to PDL cells and provide conditions for cell proliferation, therefore can be indicated for use as storage media for avulsed teeth. Though the solution is efficient but due to lack of availability and high cost the practical usage of viaspan must be considered judiciously.

\section{- Gatorade}

It is a non-carbonated sports drink that mainly consists of water, sucrose, and glucose, fructose syrups, citric acid, sodium chloride, sodium citrate, monopotassium phosphate, flavouring and colouring agent. It has a $\mathrm{pH}$ of 3 and an osmolarity of $280-360 \mathrm{mosm} / \mathrm{kg}$. Gatorade preserves more viable cells than tap water. It only serves as a storage medium if other media are not available.

\section{- Propolis}

It is a sticky resin that sweeps from the buds of trees and mainly consists of resin, waxes fatty acids, essential oils, pollen proteins and other organic compounds and minerals. Due to its antiseptic, antibiotic, antifungal, antiviral, antioxidant, anticarcinogenic, antithrombotic and immunomodulatory properties considered as a promising medium for the maintenance of avulsed teeth. Propolis can act as a good alternative natural storage medium for an avulsed tooth.

\section{- Contact lens solution}

It is considered as the most convenient preservation medium for teeth after avulsion injuries as these solutions available everywhere. It mainly contains a buffered isotonic saline solution with the addition of preservatives that may preserve the viability of PDL cells. But some subsequent studies show that the preservatives in contact lens solution are worse and lead to PDL cell necrosis, therefore they are not recommended.

\section{- Egg white}

The osmolarity of egg white is $300 \mathrm{mosm} / \mathrm{kg}$. It has shown better cell viability and significantly higher incidence of PDL healing as compared to milk for the same amount of time. It is considered as a good choice because of its high protein content, water, vitamins, lack of microbial contamination, and easy accessibility.

Egg white has been observed as an excellent medium for up to $10 \mathrm{hrs}$ with the principle advantage being its availability.

\section{- Eagle's Medium}

Eagle's medium consists of $4 \mathrm{ml}$ of L-Glutamine; $105 \mathrm{IU} / \mathrm{L}$ of Penicillin; $100 \mu \mathrm{g} / \mathrm{mL}$ of Streptomycin, $10 \mu \mathrm{g} / \mathrm{mL}$ of Nystatin and calf serum $(10 \% \mathrm{v} / \mathrm{v})$. It has high viability, mitogenic and clonogenic capacity up to $8 \mathrm{hrs}$ of storage at $4 \mathrm{c}$. The eagles medium at $37{ }^{\circ} \mathrm{C}$ (Biological Industries) is a recommended storage medium as it can preserve the PDL for extended periods before reimplantation.

\section{- L-DOPA}

Drug with possible mitogenic effects and promoter of healing. Its stimulates dopaminergic systems in the anterior portion of the pituitary gland to secrete growth hormone, which is considered as a promoter of the healing process.

It can be used as a preserving medium for avulsed teeth.

\section{- Coconut water}

Coconut water is rich in amino acid, proteins vitamins and minerals. It has high osmolarity and can be used as potential interim storage for an avulsed tooth. Though coconut water has a $\mathrm{pH}$ of 4.1 which is deleterious to cell metabolism. However, the use of coconut water is not feasible under clinical conditions.

Table 4: Categorization of storage media according to their efficacy

\begin{tabular}{|c|c|c|}
\hline S. No & Storage Media & Efficacy \\
\hline 1. & Saline & Inefficient \\
\hline 2. & Tap water & Inefficient \\
\hline 3. & Saliva & Inefficient \\
\hline 4. & Milk & Highly efficient \\
\hline 5. & HBSS & Highly efficient \\
\hline 6. & Viaspan & Lesficient \\
\hline 7. & Gatorade & Highly efficicient \\
\hline 8. & Propolis & Less efficient \\
\hline 9. & Emdogain & Moderately efficient \\
\hline 10. & Egg white & Less efficient \\
\hline 11. & Eagles Medium & Less efficient \\
\hline 12. & L-DOPA & Moderately efficient \\
\hline 13. & Cocunut water & Inefficient \\
\hline 14. & Contact lens solution & \\
\hline
\end{tabular}

\section{Conclusion}

It is to be concluded that there are no single wet storage media posses all the required characteristics for an ideal storage medium i.e capable of preserving the vitality of PDL cells, compatible physiologic $\mathrm{pH}$ and osmolarity, minimal microbial contamination, and high availability. Based on literature saline, tap water, saliva, Gatorade, contact lens solution are inefficient and have been considered non-physiological and are not recommended due to factors such as $\mathrm{pH}$ and osmolarity Eagles medium and L- dopa are less effective and not feasible due to factors like lack of availability and cost. HBSS and milk are highly efficient due to its favourable factors like highly physiologically compatible $\mathrm{pH}$ and osmolarity, low or no bacterial content. To sum up after taking all factors into account, milk is the most appropriate wet storage media for an avulsed tooth. 


\section{References}

1. Marwah N. Text book of Pediatric Dentistry. 3rd ed. New Delhi: Jaypee Brothers Medical Publishers (P) Ltd., 2014. [Google Scholar]

2. Sanghavi T, Shah N, Parekh V, Singbal K. Evaluation and comparison of efficacy of three different storage media, coconut water, propolis, and oral rehydration solution, in maintaining the viability of periodontal ligament cells J Conserv Dent. 2013; 16(1):71-74. [PMC free article] [PubMed] [Google Scholar]

3. Harkacz O, Carnes D, Walker W. Determination of periodontal ligament cell viability in the oral rehydration fluid Gatorader and milk of varying fat content. J Endod. 1997; 23:687-690. [PubMed] [Google Scholar]

4. Schwartz O, Andreasen FM, Andreasen JO. Effects of temperature, storage time and media on periodontal and pulpal healing after replantation of incisors in monkeys. Dent Traumatol. 2002; 18:190-195.

5. Sae-Lim V, Lim LP. Dental trauma management awareness of Singapore pre-school teachers. Dent Traumatol. 2001; 17:71-76.

6. Tooth replantation: a review of literature. Dent Traumatol. 2008; 24:277-282.

7. Casaroto AR, Hidalgo MM, Sell AM, Franco SL, Cuman RKN, Moreschi E et al. Study of the effectiveness of propolis extract as a storage medium for avulsed teeth. Dent Traumatol. 2010; 26:323-331.

8. Andreasen JO, Andreasen FM, Andersson L. Textbook and color atlas of traumatic injuries to the teeth, 4 th edn. Oxford: Blackwell Munksgaard, 2007.

9. Andreasen JO, Borum MK, Andreasen FM. Replantation of 400 avulsed permanent incisors. Factors related to root growth. Endod Dent Traumatol. 1995; 11:69-75.

10. Andreasen JO, Borum MK, Jacobsen HL, Andreasen FM. Replantation of 400 avulsed permanent incisors. Diagnosis of healing complications. Endod Dent Traumatol. 1995; 11:51-58.

11. Flores MT, Aandersson L, Andreasen JO, Bakland LK, Malmgren B, Barnett $\mathrm{F}$ et al. Guidelines for the management of traumatic dental injuries. II. Avulsion of permanent teeth. Dent Traumatol. 2007; 23:130-136.

12. Oreira-Neto JJ, Gondim JO, Raddi MS, Pansani CA. Viability of human fibroblasts in coconut water as a storage medium. Int Endod J. 2009; 42(9):827-830. [PubMed] [Google Scholar]

13. Subramaniam P, Girija P, Eswara U, Girish Babu KL. Oral rehydration salt-liquid as a storage medium for avulsed tooth. Dent Traumatol. 2015; 31(1):62-66. [PubMed] [Google Scholar]

14. Hwang JY, Choi SC, Park JH, Kang SW. The use of green tea extract as a storage medium for the avulsed tooth J Endod. 2011; 37(7):962-967. [PubMed] [Google $\underline{\text { Scholar] }}$ 